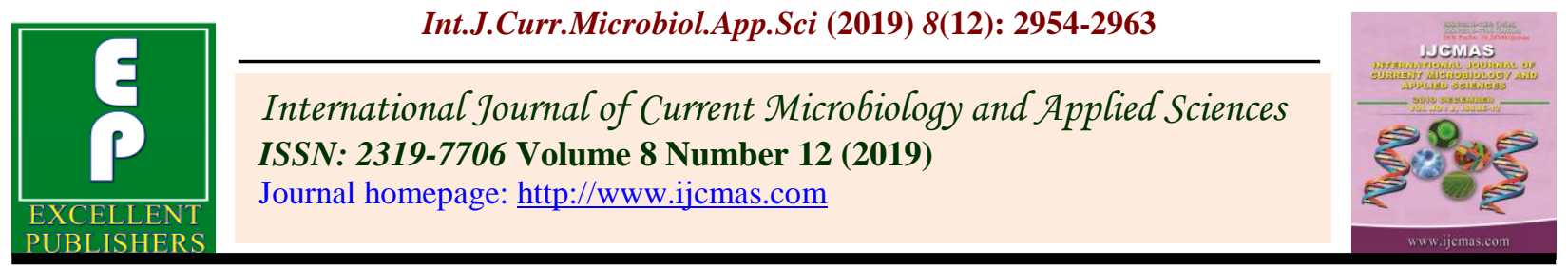

Original Research Article

https://doi.org/10.20546/ijcmas.2019.812.343

\title{
Optimization Process Parameters of Foam Mat Drying in Totapuri Mango Pulp with Foaming Agent GMS
}

\author{
Baljor Singh, RamNath Shukla, Kunal Singh* and Shweta Singh \\ Department of Food Process Engineering, Sam Higginbottom University of Agriculture \\ Technology \& Sciences, Allahabad, Uttar Pradesh, India \\ *Corresponding author
}

Keywords

Mango, Foam Mat Drying, Glycerol mono-stearate, Egg White, ash content

Article Info

Accepted:

20 November 2019

Available Online:

10 December 2019

\section{A B S T R A C T}

Mango is widely preferred because of its excellent flavour and nutritional quality. Mango pulp from Totapuri was extracted and then was subjected to foam mat drying along with 5, 7, and 9\% GMS and later with egg white as foaming agents and then dried at temperatures of 60,70 and $80^{\circ} \mathrm{C}$. Weight loss was used to estimate change in moisture ratio with respect to time and effective diffusivity. Three thin layer drying models were fitted to get the best fit model, which was selected on the basis of various statistical parameters. Wang and Singh model was found to be best in almost all cases. Nutritional status in terms of ash content was estimated and it was observed that there was significant effect of drying temperatures, GMS and egg white concentration. Based on above parameters it was resolved that foam mat drying using 5\% GMS and egg white at $60^{\circ} \mathrm{C}$ air- drying temperature was the best combination.

\section{Introduction}

Mango (Mangifera indica L) is a highly seasonal tropical fruit, very popular among millions of people in the tropics. It also occupies a prominent place among the best fruits of the world. However, it is in constant demand, there is a pre-harvest scarcity and at times a post-harvest glut for this fruit. Mango is currently ranked $5^{\text {th }}$ in total world production among the major fruit crops (FAO,
2004). Global production of mangos is concentrated mainly in Asia and more precisely in India being the leading producer in the world. Mango commonly known as king of fruits is a major fruit in Asia and around the world. India being the largest producer of mango contributes $37 \%$ of 30.5 million tons of global production (Hymavathi and khader, 2005). The Lalpatta variety is mainly cultivated in India and Pakistan (Rathore et al., 2007). In India, the name Lalpatta is 
believed to be derived from that of a village between Hyderabad and Tamil Nadu.

The genesis of this variety was as a result of a superior chance-seedling in the southern garden. It is well distributed all over the IndoGangetic plain and Bengal in the North, and as far as Hyderabad (Deccan) in the South. Thus, Lalpatta is one of the most popular mango varieties in Southern India (Gupta and Jain, 2014).

The fruit has excellent flavor, attractive colour, and delicious taste with high nutritional value. Due to higher moisture content (85\%), it has very poor keeping quality and cannot withstand any adverse climatic conditions during results in loss of 30 per cent of fruits every year (Thind, 2002). India dominates the world trade of processed mango, though hardly $1-2 \%$ of the total mango produced in India is processed. However, only $20 \%$ of the processed mango products is being exported, out of which mango pulp accounts for $80 \%$ of the exported products. The postharvest losses of mango were estimated at around 25 - 40\% (Vijayanand et al., 2015). To increase the availability of this fruit throughout the year, the surplus production must be processed into a variety of valueadded products (Saxena and Arora, 1997; Srinivasan et al., 2000; Singh et. al., 2005).

Mangos can be processed into a number of unique products such as dried mango pieces, chutney and mango leathers (Azeredo, et al., 2006). Dried mango products could successfully serve this purpose. Processing of mangos enables exporters to serve their markets even during 'off season' periods for fresh fruits. In addition, the mango varieties have a length and width of 9.87 and $4.80 \mathrm{~cm}$ respectively.

Fruit weight of $175.62 \mathrm{~g}$, seed weight of 22.99 $\mathrm{g}$, peel weight of 33.47 and pulp weight of 115
The fruit size ranges from small to medium having average dimension of $13^{\wedge} 8 \mathrm{~cm}$ and weighs between 130 and $260 \mathrm{~g}$; it's shape ranges from oblong to oblong-oblique; and has a rounded to obliquely rounded base. It has sweet taste, pleasant flavor, firm flesh, attractive cadmium yellow pulp and has no fiber. It may have scanty or moderately abundant juice. It also has good keeping and peeling quality (Gangolly et al., 1957).

In terms of physicochemical properties, the Lalpatta mango matures in 116 days and produces about 34 fruits per panicle with each fruit producing $141 \mathrm{mg}$ (per $100 \mathrm{~g}$ ) of vitamin C (Jilani et al., 2010). Among which 69 species are mostly confined in the tropical region (Medina and Garria, 2002).

\section{Materials and Methods}

The experimental studies were carried out in the Department of Food Process Engineering, Vaugh Institute of Agricultural Engineering and Technology, SHUATS Allahabad. The methodology adopted has been described under the following headings.

\section{Plan of work}

Every research study is based on an experimental plan shows the basic experimental structure which was followed to conduct this study. Fresh mango (Magnifera indica L.) Totapuri and Dushehri was purchased from local fruit sellers in Allahabad, India, Saharanpur Up India, Rohtak Haryana India. As soon the mangoes were purchased they were subjected to the processing for the development of the product.

GMS (Glycerol mono stearate) was purchased to be used as one foaming agent. Egg white was purchased from the local vendors and was separated for whites to be used as the foaming agent for the process. 


\section{Extraction of mango pulp}

Fresh fully ripe sound Totapuri mangoes will be used for extraction of pulp. Firstly ripe mangoes were washed within clean water then fruits were peeled by knife. Pulp will be collected by squeezing the flesh of mangos. The pulp was blended in an electric blender. The mango pulp contains $15.1 \%$ total solid. It will be stored in a deep freeze at a temperature of $-18^{\circ} \mathrm{C}$ for future use.

\section{Totapuri mango}

\section{Processing of mango pulp}

The mango was kept at refrigeration temperature until the time of the experiment. The mango was removed from the refrigerator before conducting an experiment and kept at ambient temperature for 2 hours to achieve equilibrium. The mango was peeled and then sliced into rectangular slabs of an average thickness of $5 \mathrm{~mm}$ each. Fresh mango pulp contains $15.1 \%$ of total solid. So pulp TSS $\%$ age should be increase for quality mango pulp processing. First all fresh mango pulp poured into a bowl. Then the bowl will be heated at $80-90^{\wedge} \mathrm{C}$ until Total Soluble Solid (TSS) \%age become 30 .

\section{Preparation of mango pulp}

At first processed mango, pulp will be taken and weighted by a balance. Then total mango pulps will be separated into three parts in order to processing of three kinds of sample. After that mango pulps will be mixed with weighted according to the described formulation. Mixed pulp will be heated at 60$80 \mathrm{C}$ for 30 minutes and cooled. Then mixture will be placed on a steel tray and smeared with very thin layer of polyethylene to preserve sticking of mango pulp after drying. The mixture will be dried by using tray dryer with constant temperature $70^{\circ} \mathrm{C}$ a maximum period of 6.5 hours. After drying sheet will be cut into (4"x1"xvarious thickness) bar form. The mango pulp were packed with high density polyethylene bag and low density polyethylene bag and stored at room temperature.

\section{Sensory analysis of finished product}

Sensory attributes including color, aroma, taste and overall acceptability is determined by hedonic rating tastes as recommended by Ranganna (2007). Hedonic rating taste is used for evaluation of sensory characteristics. This test is used for acceptability by consumer for the product. The detail methodology is presented below. A panel of 5 expert judges of different age group having different habit will be selected and sample will be serving to them.

\section{Results and Discussion}

This chapter deals with the results of all testing performed on the final samples of "Optimization process parameters of foam mat drying in mango pulp" to show that which sample or samples are the best and appropriate for the foam mat drying purpose. This chapter has been completed by considering all the parameters and results for each sample.

\section{Drying characteristic of mango pulp}

The chemical, physical, and organoleptic evaluation of mango leather had been carried out. Studies on quality were based on physicochemical analysis (i.e., moisture, ash content, foaming density, foaming stability and texture analysis) and characteristics, which were determined for fresh and stored samples.

The moisture content of mango leather increased linearly with increase in concentration of mango pulp. The results for 
moisture content of mango leather was similar with the results obtained by the researchers who in-corporated papaya in preparation of the papaya leather and found that moisture content was found to increase with coarse of time. Moisture reduction was higher at initial stages and then started to decrease with the increasing of drying time. Concentrations of foaming agent and drying temperatures have significant effect on drying process. Totapuri mango foamed with 9\% GMS \& Egg white concentration took less than time with 7\% and 5\% GMS \& egg white. Drying time was lower at $80^{\circ} \mathrm{C}$ as compare to $70^{\circ} \mathrm{C} \& 60^{\circ} \mathrm{C}$. For all experiments moisture content was higher at initial stage of drying and after then decreased with coarse of time. Graphically representation was shown in fig.

In dussehri mango pulp, $\%$ moisture score for control sample was found to be $9.2 \%$ at temperature $60^{\circ} \mathrm{C}$ for $420 \mathrm{~min}$, GMS $5 \%$ sample moisture was $8.8 \%$ at $60^{\circ} \mathrm{C}$ for $420 \mathrm{~min}$, GMS $7 \% 8.2 \%$ was $60^{\circ} \mathrm{C}$ in 420min,, GMS 9\% sample have moisture content $\%$ at $60^{\circ} \mathrm{C}$ for 420 min shown in figure 4.2

In Totapuri mango pulp, $\%$ moisture score for control sample was $9.3 \%$ at temperature $60^{\circ} \mathrm{C}$ at $420 \mathrm{~min}$, Egg white 5\% sample have moisture content of $8.1 \%$ at $60^{\circ} \mathrm{C}$ for $420 \mathrm{~min}$ Egg white $7 \%$ sample have $8.0 \%$ at $60^{\circ} \mathrm{C}$ for 420min, Egg white 9\% sample have $7.3 \%$ moisture at $60^{\circ} \mathrm{C}$ for $420 \mathrm{~min}$ Similarly for sample at 70 and $80^{\circ} \mathrm{C}$ respectively shown in figure. The mango blend contains mango pulp and foaming agents to retain the moisture.

In totapuri ash content in the food stuff represents inorganic matters remaining after the organic matters have been burnt. The \% ash score for sample A(control)was $1.81 \%$, $1.77 \%$ GMS 5\%, $1.53 \%$ GMS 7\%,1.47\% GMS 9\%,1.75\% Egg white $\%, 1.54 \%$ Egg white 7\%,1.49 \% Egg white 9\%. Similarly sampleat 70 and $80^{\circ} \mathrm{C}$ show decrease in ash level which shows the effect of different treatment and storage periods on $\%$ ash content.

Table.1 Effect of Egg white concentration and whipping time on foam stability of mango pulp (Totapuri)

\begin{tabular}{|c|c|c|c|}
\hline S. No. & Variables/Parameter & Levels & Description \\
\hline 1 & Product & 2 & Mango Pulp(totapuriMango) \\
\hline & & & Foaming agent (Glycerol mono stearate \& \\
\hline 2 & Ingredients & 6 & Egg white) with varying concentration of 5,7 , and $9 \%$. \\
\hline 3 & Processing & 3 & Tray Dryer $\left(60^{\circ} \mathrm{C}, 70^{\circ} \mathrm{C}, 80^{\circ} \mathrm{C}\right)$ \\
\hline \multirow[t]{2}{*}{4} & $\begin{array}{l}\text { Physico-chemical } \\
\text { Analysis }\end{array}$ & 6 & $\begin{array}{l}\text { Moisture Content, Total ash, Ph, Foaming density, } \\
\text { Foaming stability, Foaming Expansion }\end{array}$ \\
\hline & & & [Control sample $2+$ sample with foaming \\
\hline 5 & Total Sample & 216 & $\begin{array}{l}\text { agent }(2 \text { mango variant } \times 4 \text { ratio of foaming agents) }] \times \\
\text { thee different temperatures }\left(60^{\circ} \mathrm{C}, 70^{\circ} \mathrm{C}, 80^{\circ} \mathrm{C}\right) \times 3 \\
\text { replication }=90\end{array}$ \\
\hline
\end{tabular}


Fig.1 Effect of GMS Foaming Agents Concentration on Moisture Content During Drying at $60^{\circ} \mathrm{C}$ Temperature

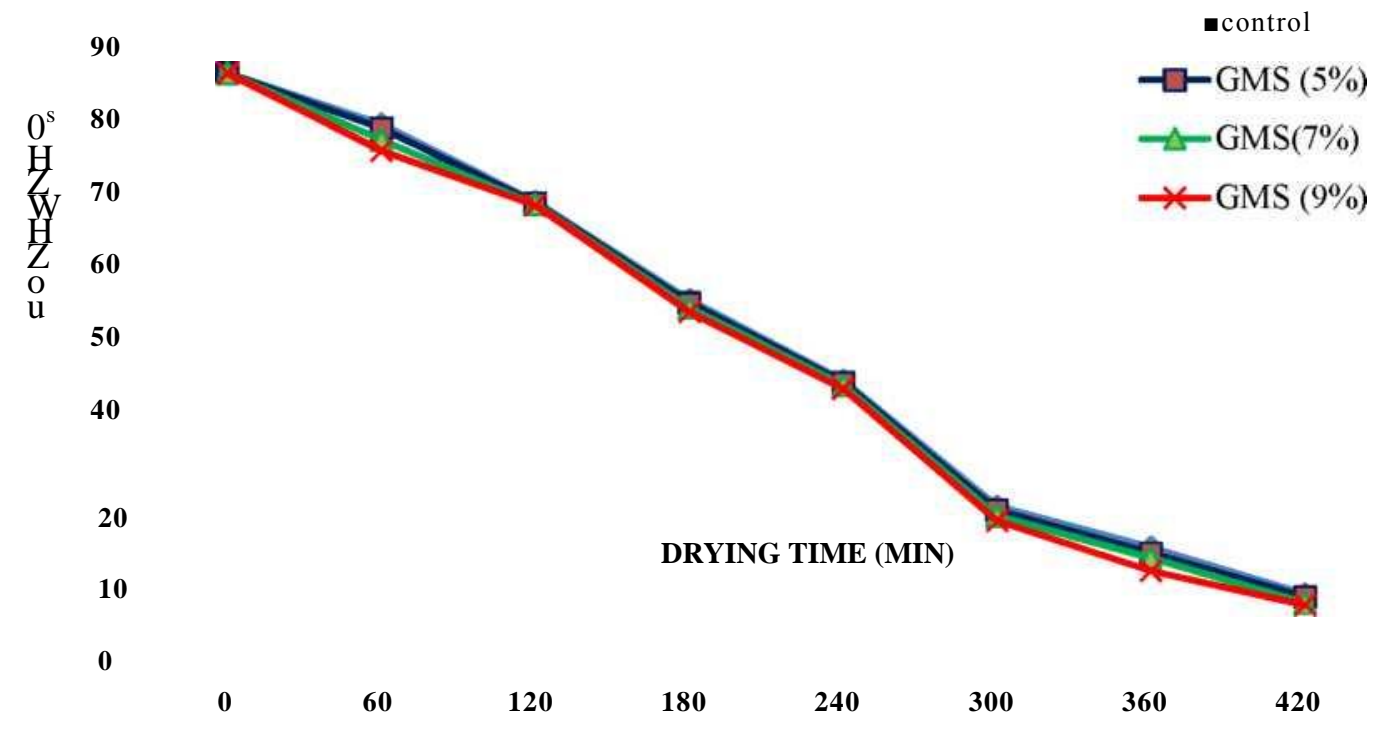

Fig.2

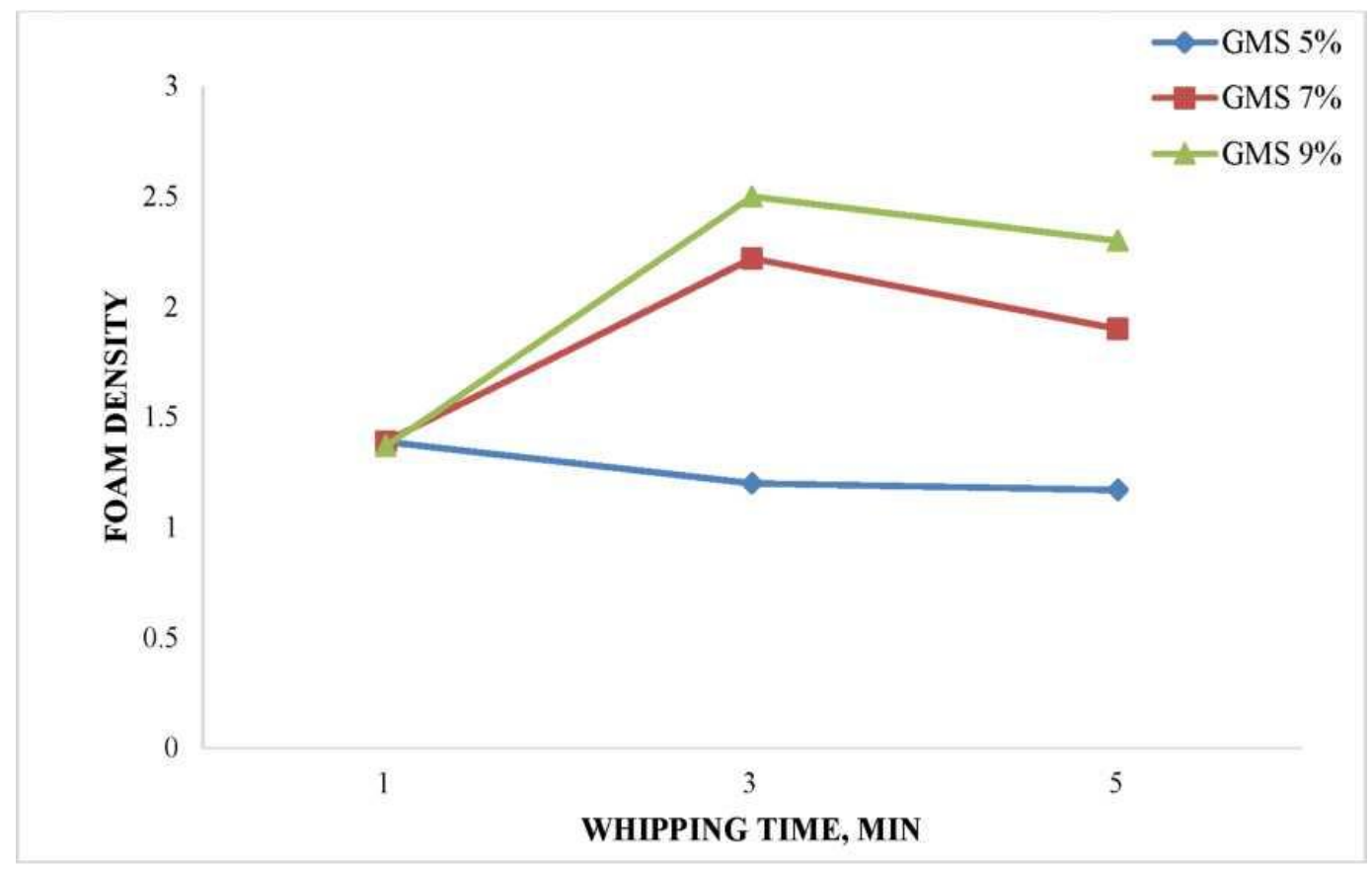


Fig.1 Effect of different treatments on Ash content of Dussehri mango pulp

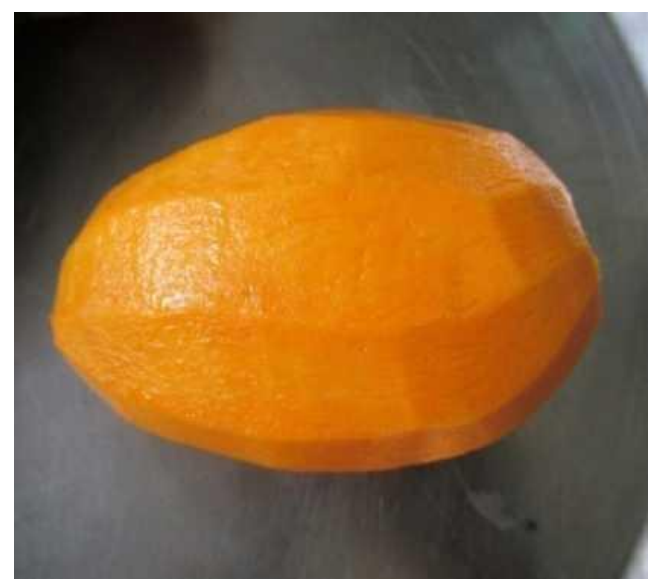

In totapuri mango pulp, \% moisture score for sample control $9.3 \%$ at temperature $60^{\circ} \mathrm{C}$ in $420 \mathrm{~min}$, GMS $5 \% 8.9 \%$ was $60^{\circ} \mathrm{C}$ in $420 \mathrm{~min}$, , GMS $7 \% 8.1 \%$ was $60^{\circ} \mathrm{C}$ in $420 \mathrm{~min}$,

It is evident that the calculated value of $F$ due to treatment is greater than the tabulated value at $5 \%$ probability level From the ANOVA. Therefore it can be concluded that significant effect of ash content of sample A, B, C and D.

Mango pulp having GMS 5\%,7\% and 9\%, the increase in volume of foam was $20 \%, 21.66 \%$ and $25 \%$ for totapuri and $25 \%, 28.33 \%$ $\& 31.66 \%$ respectively when whipped for 1 $\min$.

While the mango pulp foam was whipped for 3 min having GMS concentration 5\% \&7\% is expended upto $95 \%$ whereas for 9\%GMS concentration, Mango pulp foam is expended upto $66.66 \%$. Increase in whipping time from 3 and 5 min the volume of mango pulp foam expended to $63.33 \%, 71.66 \%$ \& $81.66 \%$ for Totapuri and $76.66 \%, 93.33 \%$ \& $101 \%$ for dussehri for GMS concentration 5\%, 7\% \& 9\% respectively. The effect of duration of whipping on foam expansion in mango pulp at different concentration of GMS and egg white.

Mango pulp having egg white 5\%,7\% and 9\%, the increase in volume of foam was $23.33 \%, 25 \%$ and $30 \%$ for totapuri and $25 \%, 28.33 \% \quad \& 31.67 \%$ respectively when whipped for $1 \mathrm{~min}$. While the mango pulp foam was whipped for 3 min having egg white concentration $5 \% \& 7 \%$ is expended upto $95 \%$, whereas for $9 \%$ egg white concentration, Mango pulp foam is expended upto $66.66 \%$.

Increase in whipping time from 3 and 5 min the volume of mango pulp foam expended to $63.33 \%, 71.66 \% \& 81.66 \%$ for Totapuri and $70 \%, 91.66 \%$ \& $101.66 \%$ for dussehri for egg white concentration $5 \%, 7 \%$ \& $9 \%$ respectively.

Foam stability reflects the water holding capacity of the foam and one way to determine the rate at which the liquid drains from it (Kampetal. 2003).The stable foam structure is desirable for rapid drying and ease of removing the dried material from the tray. If foams break or drain excessively, drying time is increased, reducing product quality. The stability/drainage volume of foam is influenced by the thickness of the interface, foam size distribution, interface permeability, and surface tension. The concentration of foaming agent is one of the major factors in foam stability. It is seen that the foam with higher concentration of GMS exhibited more stability as compared to lower concentration of GMS. However, crease in pulp concentration caused decrease in stability of foam and increase in drainage volume. Increase in GMS concentration caused 
stability of foam or decrease of drainage volume.

Foam stability reflects the water holding capacity of the foam and one way to determine the rate at which the liquid drains from it. The drainage is accompanied by a progressive thinning in the lamella and can increase the probability of the film of the foam volume over the course of time. The stable foam structure is desirable for rapid drying and ease of removing the dried material from the tray. If foam break or drains excessively, drying time is increased, reducing product quality. The concentration of foaming agents is one of the major factor in stability.

Effect of GMS and whipping time on foam density of tomato pulp. The foam density measured after incorporating the air into the tomato pulp by whipping. During whipping process, air is brought in to liquid puree and entrapped in the liquid as bubble. Density of tomato puree decreased from $0.93 \mathrm{~g} / \mathrm{ml}$ to $0.54 / \mathrm{ml}$ for concentration $0.50-1.00 \%$ when whipped for both concentrations $0.50 \%$ and $0.75 \%$ and foaming density increase to 0.71 g.ml for $1.00 \%$ when whipped for $3 \mathrm{~min}$. Decrease in the foam density indicate that more volume of air trapped in the foam during whipping process. Requirement to produce easily detrayable foams after drying is dependent on the ability to produce foams with low densities between 0.4 to $0.6 \mathrm{~g} / \mathrm{ml}$ (Ratti and kudra, 2006).

The present investigation on "Optimization process parameters of foam mat drying in mango pulp" prepared from mango pulp and foaming agents was undertaken in the Department of Food Process Engineering, Vaugh School of Agriculture Engineering and Technology, Sam Higginbottom University of Agriculture, Technology and Sciences Allahabad. In the present investigation efforts were made to enhance the nutritional quality of mango pulp by incorporating mango, foaming agents (Glycerol mono stearate \& Egg white).

Totapurimango samples using different concentration of GMS $(5,7 \& 9 \%)$ of which $5 \%$ was found to be most effective with respect to foam mat drying.

Totapurimango samples using different concentration of Egg white (5, 7 \& 9\%) of which 5\% was found to be most effective with respect to foam mat drying.

No significant changes were observed in ash content on dussehrisamples with foaming agents.

Foam expansion was highest for totapurifor GMS concentration 9\% 25.Foam expansion was highest for totapurifor Egg white concentration 9\% 28.33.Foam stability was highest for totapurifor GMS concentration 9\% 60.Foam stability was highest for totapurifor Egg white concentration 7\% 56.25.Foam density was highest for totapurifor GMS concentration $5 \%$ 1.38. Foam density was highest for totapurifor Egg white concentration 5\% 1.35. The above research works showed that the Mango pulp treated with foaming agent shows reduce in moisture content and increase in drying rate as compare to normal mango pulp without foaming agent. Foaming volume was also found to increase in treated mango samples. Ash content remains the same in all treated samples. Weight loss was used to estimate change in moisture ratio with respect to time. From all treated samples foam mat drying using 5\% egg white and 5\% GMS at $60^{\circ} \mathrm{C}$ air drying temperature shows best results. Further increase in egg white and GMS concentration either had similar or negative impact on drying.

\section{References}

Abano E. E., \& Sam-Amoah L. K. (2011). Effects of Different Pretreatments on Drying Characteristics 
of Banana Slices. ARPN Journal of Engineering and Applied Sciences, 6(3), 121-129.

Ahmed J. (1997). Dehydration of turnip and radish slices. J. Food Sci. Technol., India. 34(5): 410-412.

Ajila, C. M., Bhat, S. G., \& Rao, U. P. (2007). Valuable components of raw and ripe peels from two Indian mango varieties. Food Chemistry, 102(4), 10061011.

Akoy E. A. O., Horsten D. V. \&Luecke W. (2008). Drying Kinetics and Colour Change of Mango Slices as Affected by Drying Temperature and Time. Tropentag International Conference on "Competition for Resources in a Changing World: New Drive for Rural Development ”, (pp. 1-6). Hohenheim.

Akoy E. O. (2014). Experimental characterization and modeling of thin-layer drying of mango. International Food Research Journal, 21(5), 1911 1917.

Akoy, E. O. M. (2014). Experimental characterization and modeling of thin-layer drying of mango slices. International Food Research Journal, 21(5).

Al-Amin M., Hossain M. S. \& Iqbal A. (2015). Effect of Pre-treatments and Drying Methods on Dehydration and Rehydration Characteristics of Carrot. Universal Journal of Food and Nutrition Science, 3(2), 23-28.

AmeeRavani and D. C. Joshi (2013). Mango and it's by product utilization, Trends in post Harvest Technology, volume 1, page 55-67.

Ammu, K., Krishnappa, K. G., Subramanian, V., Sharma, T. R., \&Nath, H. (1976).

analysis of marketing mix of various mango pulp brands in south Gujarat. Asian J. Dairy \& Food Res, 33(3), 209-214.

AremuAdemolaKabiru, AdedokunAdetayo Joshua \&AbdulganiyOlayinkaRaji (2013). Effect of Slice Thickness and Temperature on the Drying Kinetics of Mango (MangiferaIndica).IJRRAS, 15(1), 41-50.

Asumeng L. (2009). Quality and drying characteristics of infrared dried mango sweet potato leather. A thesis submitted to the department of food science \& technology, Kwane,Nkrumah university of science and technology.

AtunguluKabiru, A. A., Joshua, A. A., \&Raji, A. O. (2013). Effect of slice thickness and temperature on the drying kinetics of mango (Mangiferaindica). International Journal of Research and Review in Applied Sciences, 15(1), 41-50.

Augustin J., Swanson B. G. and Huang C. P. (1979). Changes in nutrient composition of dehydrated potato products during commercial processing. $J$. Food Science, 44(1): 216-219.

Auisakchaiyoung, T. and Rojanakorn, T.(2015). Effect of foam-mat dryingcondition on quality of dried Grc fruit (Momordicacochinchinensis) april, International Food Research journal 22(5):20252031.

Azeredo M. C., Brito S., Moreira E. G. \& Bruno M.
(2005). Effect of drying and storage time on the physico-chemical properties of mango leathers. International Journal of food science \& technology.

Azeredo, H., Brito, E. S., Moreira, G. E., Farias, V. L., \& Bruno, L. M. (2006).

Bag, S. K., Srivastav, P. P., \& Mishra, H. N. (2011). Optimization of process parameters for foaming of bael (Aeglemarmelos L.) fruit pulp. Food and Bioprocess Technology, 4(8), 1450-1458.

Baker C. G. (1997). Industrial Drying of Foods. (P. Baker, C. G. Baker, \& B. C. Baker, Eds.) Springer.

Barros Fernandes, R. V., Queiroz, F., Botrel, D. A., Rocha, V. V., de Lima, C. F., \& de Souza, V. R. (2013). Foam mat drying of tomato pulp. Bioscience Journal, 29(4).

Bonazzi C. \&Domoulin E. (2011). Quality Changes in Food Materials as Influenced by Drying Processes in Modern Drying Technology Volume 3, Product Quality and Formulation, First Edition. Tsots as, E. and Mujumdar, A. S. (Eds). (pp. 1-20) Wiley- VCH Verlag GmbH \& Co. KGaA.

Bose T. K. and Mitra S. K. (1990). Fruits in tropical and subtropical, NayaProkash, Calcutta, pp. 250-275.

Brygidyr, A. M., Rzepecka, M. A., \& McConnell, M. B. (1977). Characterization and drying of tomato paste foam by hot air and microwave energy. Canadian Institute of Food Science and Technology Journal, 10(4), 313-319.

Caparino O. A., Tang J., Nindo, Sablini S. S., Powers J. K.(2012). Effect of drying methods on the physical properties and microstructure of mango powder. Journal of food engineering, Vol 111.

Chandrasekar V., JhonSwamy Gabriela, K. Khannan and A. Sangamithra(2015).

Chattopadhyay, Guha, S., Ghosal, S., U. (1996). Antitumor, immunomodulatory and anti-HIV effect of mangifera in a naturally occurring glucosylxanthone. Chemotherapy, 42(6), 443-451.

Chen J. P., Tai C. Y., \& Chen B. H. (2007). Effects of different drying treatments on the stability of carotenoids in Taiwanese mango (Mangiferaindica L.). Food Chemistry, 100, 1005-1010. doi:10.1016/j.foodchem.10.056.

Chen X. D., \&Mujumdar A. S. (2008). Drying Technologies in Food Processing. Blackwell Publishing Ltd.

Corzo O., Bracho N. (2008). Water diffusion coffiecient of mango slices at different maturity stages during airdrying.Journal of engineering 87,479-484.

Crapiste G. H. \&Rotstein E. (1997). Design and Performance Evaluation of Dryers. In K. J. Valentas, E. Rotstein, \& R. P. Singh (Eds.), Handbook of Food Engineering Practice(pp. 132173). New York: CRC Press LLC.

Darvishi H., Azadbakht M., Rezaeiasl A. \&Farhang A. (2013). Drying characteristics of sardine fish dried with microwave heating. Journal of the Saudi Society of Agricultural Sciences, 12, 121-127.

Davoodi M. G., Vijayanand P., Kulkarni S. G. \&Ramana 
K. V. (2007). Effect of Different Pre-treatments and Dehydration Methods on Quality Characteristics and Storage Stability of Tomato Powder. Swiss Society of Food Science and Technology, 40, 18321840 .

doi:http://dx.doi.org/10.1016/jjssas.09.002.

DuduyemiOladejo, Ade Omowaye B. I. O., AbioyeAdekanmi. O. (2013).

Earle D. M. (2004). Drying. In D. M. Earle, \& M. D. Earle, Unit Operations in Food Processing- the Web Edition (The Web Edition ed.). Palmerston North, New Zealand: The New Zealand Institute of Food Science \& Technology Inc. Retrieved August 31, 2015.

Effect of drying and storage time on the physico-chemical properties of mango leathers. International journal offood science \& technology, 41(6), 635-638.

Effect of foaming agent concentration and drying temperature on physiochemical and antimicrobial properties of foam mat dried powder. Asian J. Dairy \& Food Research, 34(1)2015:39-43.

Erbay Z., \& Icier F. (2009). A Review of Thin Layer Drying of Foods: Theory, Modeling, and Experimental Results. Critical Reviews in Food Science and Nutrition, 50, 441-464.

Exams A. and Lacroix C. (1989). Development of a high protein paste. Influence of processing parameters. Science Desh Aliments, 9: 285-305.

Experimental Study on Kinetics, Modeling and Optimization of Osmotic Dehydration of Mango (MangiferaIndica L.), IJES Vol(2) Issue(4). ISSN(e):2319-1813 ISSN(p):2319- 1805.

Falade, K. O., \&Oyedele, O. O. (2010). Effect of osmotic pretreatment on air drying characteristics and colour of pepper (Capsicum spp) cultivars. Journal of food science and technology, 47(5), 488-495.

Foam-Mat Dehydration Effect on the Physical Properties, Micronutrient Contents and Sensory Characteristics of Pineapple and Cashew Apple Juice Powder. British Journal of Applied Science \& Technology, $7(2), 205$.

Freeze drying of mango pulp [Mangiferaindica, storage]. Food Technology in Australia.

Fumagalli M., Brown, C., Popov, N., Takatsu, Y., Melamed, J., Fagagna, D. B. \& Gil J. Abbasi S., B. Su, R. E. Kellems, J. Yang and Y. Xia (2005). The essential role of MEKK3 signaling in angiotensin II-induced calcineurin/nuclear factor of activated Tcells activation." J BiolChem 280 (44): 36737 36746. Acosta, JC, A. O'Loghlen, A. Banito, $M V$ Guijarro, A. Augert, S. Raguz, M. atherosclerosis, 30(6), 295-300.

Gangolly, S. R., Singh, R., Katyal, S. L., \& Singh, D. (1957). Mango pulp foam-mat dried mango powder. International Food Research Journal, 20(4).

Golestani R., Raisi, A. \&Aroujalian A. (2013). Mathematical Modeling on Air Drying of Apples Considering Shrinkage and Variable Diffusion
Coefficient. Drying Technology, 31, 40-51. doi:10.1080/07373937.714826.

Goyal R. K., Kingsly A. R., Manikantan M. R. \&Ilyas S. M. (2006). Thin-layer Drying Kinetics of Raw Mango Slices. BiosystemsEngineering, 95(1), 43-49. doi: 10.1016/j.biosystemseng.05.001.

Grandison A. S. (2006). Postharvest Handling and Preparation of Foods for Processing. In J. G. Brennan, Food Processing Handbook(pp. 1-29). Weinheim, Germany: WILEY- VCH Verlag GmbH \& Co. KGaA.

Heilporn C., Wylock C., Spreutels L., \& Haut B. (2012). Experimental Analysis and Modeling of Mangoes Drying Kinetics. 18th International Drying Symposium, (pp. 1-7). Xiamen.

Hymavathi, T. V., \&Khader, V. (2005). Carotene, ascorbic acid and sugar content of vacuum dehydrated ripe mango powders stored in flexible packaging material. Journal of Food Composition and Analysis, 18(2), 181-192.

Ismail, M. A., \&IbnIdriss, E. M. (2013). Mathematical modelling of thin layer solar drying of whole okra (Abelmoschus esculentus (L.) Moench) pods. International Food Research Journal, 20(4).

J. S. Alakali, C. C. Ariahu and E. I. Kucha (2009). Kinetic of Moisture Uptake of Osmo-Foam-Mat Dried Mango Powder and Application of Sorption Isotherms to Shelf- Life prediction. American Journal of Food Technology, 4(3):119-125, 2009, ISSN 15574571.

Jangam S. V. \&Mujumdar A. S. (2010). Basic Concepts and Definitions. In S. V Jangam, C. L. Law, A. S. Mujumdar, S. V. Jangam, C. L. Law, \& A. S. Mujumdar (Eds.), Drying of Foods, Vegetables and Fruits(Vol. 1, pp. 1-30). Singapore, Singapore.

Jangam S. V. \&Mujumdar A. S. (2010). Classification and Selection of Dryers for Foods. In S. V. Jangam, C. L. Law, \& A. S. Mujumdar (Eds.), Drying of foods, Vegetables and Fruits(Vol. 1, pp. 59-82). Singapore.

Jangam, Osman, H., S. V., Lease, J. D., \&Mujumdar, A. S. (2011). Drying of low- rank coal (LRC) - a review of recent patents and innovations. Drying Technology, 29(15), 1763-1783.

Jaya S. \& Das H. (2003). Vacuum drying of mango pulp, Unpublished Ph.D. Thesis Submitted to IIT kharagpur, India, pp.

Jilani, M. S., Bibi, F., \&Waseem, K. (2010). Evaluation of physico-chemical characteristics of mango (Mangiferaindica L.) cultivars grown in DI Khan. $J$. Agric. Res, 48(2), 201-207.

Joshi. G., Shukla R., Chaudhari B., Leua A. K., \& Thakkar R. G. (2014). An

Kabiru A. A., Joshua A. A., \&Raji A. O. (2013). Effect of Slice Thickness and Temperature on the Drying Kinetics of Mango (MangiferaIndica).IJRRAS, 15(1), 4150.

Kadam, D. M., \&Balasubramanian, S. (2011). Foam mat drying of tomato juice. Journal offood processing 
and preservation, 35(4), 488-495.

Kadam, D. M., Wilson, R. A., \& Kaur, S. (2010). Determination of biochemical properties of foammat dried mango powder. International journal of food science \& technology, 45(8), 1626-1632.

Kahveci K., \&Cihan A. (2008)Dryingof Food Materials: Transport Phenomena. Nova Science Publishers Inc.

Korbel, E., Attal, E. H., Grabulos, J., \&Lluberas, E. (2013). Impact of temperature and water activity on enzymatic and non-enzymatic reactions in reconstituted dried mango model system. European Food Research and Technology= Zeitschrift fur Lebensmittel-Untersuchung und-Forschung. A, 237(1), 39.

Korbel, E., Attal, E. H., Grabulos, J., \&Lluberas, E. (2013). Impact of temperature and water activity on enzymatic and non-enzymatic reactions in reconstituted dried mango model system. European Food Research and Technology= Zeitschrift fur Lebensmittel-Untersuchung and-Forschung. A, 237(1), 39.

Kudra T. \&Mujumdar A. S. (2002). Advanced Drying Technology.New York, USA: Mercek\& Dekker Inc.

Kumar S. P. \& Sagar V. R. (2014). Drying kinetics and physico-chemical characteristics of Osmodehydrated Mango, Guava and Aonla under different drying conditions. J Food SciTechnol,51(8), 1540-1546. doi:10.1007/s13197012-0658-3.

Kumar, P. S., \& Sagar, V. R. (2014). Drying kinetics and physico-chemical characteristics of Osmodehydrated Mango, Guava and Aonla under different drying conditions. Journal of food science and technology, 1-7.

Maqbool,Campbell, J. A., Malik, A. U., Johnson, P., Dunne, A., Sun, X., Amin, M. \&

Martinez, Sagar, V. R., \& Suresh Kumar, P. (2010). Recent advances in drying and dehydration of fruits and vegetables: a review. Journal of food science and technology, 47(1), 15-26.

Maskan A., Kya S. \&Maskan M. (2002). Hot air sun drying in mango leather.Journal of food engineering, 54.

Maskan, A., Kaya, S., \&Maskan, M. (2002). Hot air and sun drying of grape leather (pestil). Journal of Food Engineering, 54(1), 81-88.

McMinn W. A. \& Magee T. R. (1999). Principles, Methods and Applications of the Convective Drying of Foodstuffs. Trans I Chem E,77(Part C),
175-193.

MehranAzizpour, MohbbatMohebbi, Mohammad Hossein Haddad Khodaparast, Mehdi Varidi (2013). FoamMat drying of Shrimp: characterization and Drying Kinetics of Foam, Agri Engineering International: CIGR journal Vol.15, No.3.

Mercer D. G. (2012). A Comparison of the Kinetics of Mango Drying in Open-Air, Solar, and Forced-Air Dryers. African Journal of Food, Agriculture, Nutrition and Development, 12(7), 6838-6852.

Mir, M. A., \&Nath, N. (1995). Sorption isotherms of fortified mango bars. Journal of Food Engineering, 25(1), 141-150.

Mirzaee E., Rafiee S., Keyhani A. \&Emam-Djomeh Z. (2009) Determining of Moisture Diffusivity and Activation Energy in Drying of Apricots. Res. Agr. Eng.,55(3), 114-120.

Morgan, W. H., Thebault, E., Seymour, C. L., \& Van Veen, F. F. (2016). Density dependence and environmental factors affect population stability of an agricultural pest and its specialist parasitoid. Bio Control, 62(2), 175-184.

Nindo, C., Sun, T., Wang, S. W., Tang, J., \& Powers, J. R. (2003). Evaluation of drying technologies for retention of physical quality and antioxidants in asparagus (Asparagus of ficinalis, L.). LWTFoodScience and Technology, 36(5), 507-516.

Ojo, O. C., Theresa, E., Adejoh, O., Okereke, R. E., Ekele, D., \&Maji, A. A. (2015).

Omayma M. Ismail and Khaled S.A. Negy (2012). Characteristics of Dried Mango Slices as Affected by Pre-Treatmant and Drying Type. Australian Journal of Basic and Applied Science, 6(5):230235,2012ISSN 1991-8178.

P.Rajkumar, R. Kailappan, R. Viswanathan, G.S.V. Raghvan (2006). Drying Characterstics of foanedalphonso mango pulp in a continous type foam mat dryer. Journal of Food Engineering 79(2007)1452-1459.

Prajapati V. K., Nema P. K. \&Rathore S. S. (2011) Effect of pretreatment and drying methods on quality of value-added dried aonla (EmblicaofficinalisGaertn) shreds. $\quad J \quad$ FoodSciTechnol,48(1), 45-52. doi:10.1007/s13197-010-0124-z.

Pushpa G., Rajkumar P., Gariepy Y. and G. S. V. Raghavan (2008). "Microwave drying of enriched mango fruit leather," in Proceedings of the Canadian Society for Bioengineering Annual Conference,

\section{How to cite this article:}

Baljor Singh, RamNath Shukla, Kunal Singh and Shweta Singh 2019. Optimization Process Parameters of Foam Mat Drying in Totapuri Mango Pulp with Foaming Agent GMS. Int.J.Curr.Microbiol.App.Sci. 8(12): 2954-2963. doi: https://doi.org/10.20546/ijcmas.2019.812.343 